KATARZYNA MAJCHRZAK

Wydział Prawa Kanonicznego

Uniwersytetu Kardynała Stefana Wyszyńskiego w Warszawie

\title{
ZAKRES NAJWAŻNIEJSZYCH \\ OBOWIAZZKÓW PRACOWNIKA W ŚWIETLE PRZEPISÓW KODEKSU PRACY
}

Treść: Wstęp. - 1. Sumienne i staranne wykonywanie pracy. - 2. Wykonywanie poleceń przełożonych. - 3. Ustawowy katalog obowiązków pracowniczych. - 3.1. Przestrzeganie czasu pracy. - 3.2. Przestrzeganie porządku i regulaminu pracy. - 3.3. Przestrzeganie przepisów przeciwpożarowych oraz zasad bezpieczeństwa i higieny pracy. - 3.4. Obowiązek dbałości pracownika o dobro zakładu pracy. - 3.5. Obowiązek przestrzegania tajemnicy. - 3.6. Obowiązek przestrzegania zasad współżycia społecznego.

- Zakończenie.

\section{Wstęp}

Obowiązki pracownika składają się na treść stosunku pracy. Ustawodawca jasno określił główny obowiązek pracownika w art. 22 k.p. tj. wykonywanie pracy określonego rodzaju na rzecz pracodawcy i pod jego kierownictwem oraz w miejscu i czasie wyznaczonym przez pracodawcę. Treść tego zobowiązania sprecyzowany został w art. 100 k.p., który wskazuje zwłaszcza na element jakościowy pracy. Przepis reguluje najważniejsze obowiązki pracownika, niezależnie od podstawy prawnej nawiązania stosunku pracy. Należy pamiętać, że nie jest to jednak katalog zamknięty. Często obowiązki pracownicze wynikają z regulaminów pracy, układów zbiorowych pracy czy tzw. pragmatyk służbowych. Ponadto każdy pracownik konkretnych zobowiązań pracowniczych, powinien szukać w postanowieniach umowy o pracę. Dlatego obowiązki, o których mowa w art. 100 k.p. 
są z pewnością obowiązkami podstawowymi i najbardziej powszechnymi, ale nie jedynymi.

\section{Sumienne i staranne wykonywanie pracy}

Obowiązek sumienności i staranności został wyrażony wprost w art. 100 \$1 k.p. Nakaz ten jednak poza ogólnym sformułowaniem nie został wyjaśniony, ponieważ nie przewidziane zostały wzorce lub kryteria wymaganej sumienności i staranności. Pracownik jest zobowiązany do świadczenia pracy w odpowiedniej ilości i o odpowiedniej jakości. Spełnienie tych warunków decyduje czy praca została wykonana właściwie tj. w sposób należyty. Miarą należytego wykonania pracy jest sumienność i staranność. Zarówno doktryna, jak i orzecznictwo zgodnie przyjmują, że pojęcie staranności wskazuje na miarę obiektywną, natomiast sumienne wykonanie pracy wiąże się ze stosowaniem kryteriów subiektywnych, zindywidualizowanych ${ }^{2}$. Nie ma jednego i uniwersalnego kryterium w oparciu o które można byłoby zbadać staranne wykonywanie pracy. W zależności od rodzaju wykonywanej pracy pracownik powinien mieć na uwadze i wykonując daną czynność spełniać wymogi natury prawnej, technicznej i organizacyjnej. Zatem funkcjonują zróżnicowane wzorce staranności, odnoszone do pracowników wykonujących określony zawód czy zajmujących określone stanowiska. Według Sądu Najwyższego wykonywanie pracy starannie oznacza stosowanie się do reguł technicznych (prakseologicznych) narzucających powinność racjonalnego postępowania, tzn. do reguł dobrej roboty, uwzględniającej reguły wiedzy praktycznej bądź w zależności od rodzaju pracy - również wiedzy naukowej ${ }^{3}$. Powyższa opinia wskazuje, że innej staranności

\footnotetext{
${ }^{1}$ Por. T. Kuczyński, Obowiązki pracownika, w: Prawo pracy, red. Z. Kubot - T. Kuczyński - Z. Masternak - H. Szurgacz, Warszawa 2008, s. 153.

${ }^{2}$ Por. M. NAŁęCZ, Obowiązki pracownika, w: Kodeks pracy. Komentarz, red. W. Muszalski, Warszawa 2013, s. 256-257.

${ }^{3}$ Por. Wyrok SN z dnia 8 kwietnia 2009 r., sygn. akt II PK 260/08, LEX nr 707876. O należytej staranności przesądza zatem znajomość reguł, jak powinien pracownik postąpić, aby podjęte przez niego czynności służyły osiągnięciu założonego rezultatu.
} 
należy wymagać od osoby zajmującej stanowisko kierownicze, innej od pracownika umysłowego a jeszcze innej od pracownika wykonującego czynności techniczne $e^{4}$.

Natomiast obowiązek sumienności dotyczy strony podmiotowej działania pracownika, zawierając odesłanie do reguł aksjologicznych (etycznych). Ten subiektywny element wyraża się w indywidualnym zaangażowaniu pracownika ${ }^{5}$. Oceniając sumienne wykonywanie pracy należy wziąć pod uwagę właściwości osobiste pracownika, takie chociażby jak doświadczenie zawodowe, zdolności psychofizyczne, predyspozycje, posiadane kwalifikacje, wiek czy sprawność fizyczną. Pracownik, który sumiennie wykonuje pracę nie oznacza automatycznie, że jest to pracownik który świadczy ilościowo pracy najwięcej. Przeciwnie sumienne wykonanie pracy zawsze jest oceniane w aspekcie indywidualnych cech pracownika. Pracownik powinien mając na uwadze swoje predyspozycje, posiadaną wiedzę i siłę fizyczną rozsądnie wykonać spoczywające na nim obowiązki. Pracownik nie powinien przekraczać granic własnej wytrzymałości. Sumienność oznacza rozwagę pracownika, który zawsze powinien ocenić na ile wystarczy mu sił psychofizycznych, doświadczenia zawodowego i kwalifikacji, aby właściwie wypełnić zobowiązanie.

Z pewnością zwiększone wymogi staranności i sumienności obowiązują na stanowiskach kierowniczych ${ }^{6}$.

Dodatkowo warto zasygnalizować, że obowiązek sumiennego i starannego wykonywania pracy aktualizuje się nie tylko wówczas,

\footnotetext{
${ }^{4}$ Odpowiedni miernik staranności należy stosować do wykonywania pracy w poszczególnych zawodach czy specjalnościach. Przykładowo w wyroku z dnia 12 czerwca 1975 r., sygn. akt I PR 415/74 (OSNC nr 4/1976, poz. 87), Sąd Najwyższy uznał, że nie można dopatrzyć się zawinionego niedopełnienia przez radcę prawnego obowiązku pracowniczego w tym, że nie wniósł odwołania od niekorzystnego orzeczenia, mając na względzie istniejące w tym czasie rozbieżne orzecznictwo w zakresie wykładni przepisów prawa.

${ }^{5}$ Por. T. Kuczyński, Obowiązki pracownika, s. 154.

${ }^{6}$ Wraz ze wzrostem twórczego waloru pracy, czyli im bardziej praca wymaga zdolności umysłowych, tym bardziej wzrasta znaczenie reguł sumienności przy ocenie sposobu wykonania pracy.
} 
kiedy pracownik realizuje swoje czynności adekwatnie do jej rodzaju i charakteru, ale również wtedy, gdy wykonuje polecenie przełożonego. Przy czym polecenie musi dotyczyć pracy i nie może być sprzeczne z przepisami prawa lub umową o pracę. Dlatego słusznym stanowiskiem wydaje się być twierdzenie, iż polecenie przełożonego powinno stanowić konkretyzację obowiązków wynikających $\mathrm{z}$ umowy o pracę, zaś bezkrytyczne wykonanie bezprawnego polecenia może być potraktowane jako naruszenie innego obowiązku pracowniczego tj. dbałości o dobro zakładu pracy?

\section{Wykonywanie poleceń przełożonych}

Ustawodawca w art. $100 \S 1$ k.p. wyraźnie wskazał, że pracownik ma obowiązek stosować się do poleceń przełożonych, które dotyczą pracy pod warunkiem, że nie są one sprzeczne z przepisami prawa lub umową o pracę. Obowiązek łączy się nierozerwalnie $z$ istotą nawiązania stosunku pracy. Jak już wyżej wspomniano każdy pracownik świadczy pracę określonego rodzaju na rzecz pracodawcy i pod jego kierownictwem, w tym także w miejscu i czasie wyznaczonym przez pracodawcę. Jednocześnie obowiązek ten wyznacza granicę tzw. podporządkowania się pracownika pracodawcy. Granicę wyznaczają trzy przesłanki: rodzaj wykonywanej pracy, niesprzeczność z przepisami prawa oraz umową o pracę $e^{8}$. Polecenie dotyczy pracy wówczas, gdy jest związane ze stosunkiem pracy. Zatem poza granicę rodzaju wykonywanej pracy wykraczają polecenia związane z załatwieniem prywatnej sprawy przełożonego lub uczestnictwa w akcji społecznej. Przy czym polecenia dotyczące pracy nie obejmują tylko samych poleceń związanych z przedmiotem świadczenia czyli z konkretnie wskazanym w umowie zobowiązaniem, ale obejmuje także wszelkie

\footnotetext{
${ }^{7}$ Por. Wyrok SN z dnia 2 czerwca 2010 r., sygn. akt II PK 364/2009, Lexis.pl nr 2583859.

${ }^{8}$ Pracownik nie ma obowiązku wykonywania poleceń wykraczających poza wskazane granice, jednakże polecenie sprzeczne np. $z$ umową o pracę ale potwierdzone przez przełożonego wiąże pracownika (ale należy to odróżnić od bezkrytycznego wykonania przez pracownika bezprawnego polecenia przełożonego). Por. Wyrok SN z dnia 10 września 1997 r., sygn. akt I PKN 244/97, LEX nr 32793.
} 
polecenia w zakresie zachowania się pracownika w określony sposób w określonym miejscu i czasie wykonywania tej pracy. Zatem te polecenia dotyczyć mogą nie tylko sposobu wykonania pracy ale również samego porządku i organizacji pracy ${ }^{9}$.

Pracownik ma obowiązek wykonać polecenia, które są zgodne z prawem. Dlatego polecenia bezprawne należy uważać za nieważne w takim znaczeniu, że nie wywołują one skutku prawnego i nie powstaje wówczas obowiązek zachowania się zgodnego $\mathrm{z}$ wydanym poleceniem $^{10}$.

Niewykonanie polecenia przełożonego narusza porządek i dyscyplinę pracy. Dlatego może stanowić podstawę do rozwiązania umowy o pracę za wypowiedzeniem, a nawet bez wypowiedzenia $\mathrm{z}$ winy pracownika ${ }^{11}$. Zdaniem Sądu Najwyższego: „Polecenia pracodawcy mogą mieć charakter sformalizowany w postaci zarządzenia przewidującego obowiązek przestrzegania przez pracownika określonych procedur. Postępowanie pracownika niezgodne z tymi procedurami, z powołaniem się na odmienną praktykę, stanowi naruszenie jego obowiązków, mogące uzasadniać wypowiedzenie umowy o pracę"12.

Należy również pamiętać, że pracownik nie dokonuje oceny merytorycznej otrzymanego polecenia służbowego. Dlatego jeżeli nie jest ono sprzeczne z prawem pracownik powinien je wykonać. Nawet krytyczny stosunek pracownika do wydawanych poleceń przez przełożonego, nie zwalnia pracownika z powinności jego wykonania. Bowiem ocena czy zadanie objęte poleceniem służbowym jest

\footnotetext{
${ }^{9}$ Por. T. Kuczyński, Obowiązki pracownika, s. 154.

${ }^{10}$ Por. L. Florek, Prawo pracy, Warszawa 2014, s. 163.

${ }^{11}$ Odmowa wykonania polecenia wiąże się z ryzykiem pracownika, że zostaną wobec niego zastosowane przez pracodawcę sankcje, a sąd (ewentualnie rozstrzygający ten spór) podzieli punkt widzenia pracodawcy. Bowiem bezprawna i świadoma odmowa wykonania polecenia, zagrażająca istotnym interesom pracodawcy, uzasadnia rozwiązanie umowy o pracę bez wypowiedzenia $\mathrm{z}$ winy pracownika (w trybie art. 52 \$1 pkt 1 k.p.). Por. Wyrok SN z dnia 12 czerwca 1997 r., sygn. akt I PKN 211/97, OSNAPiUS nr 11/1998, poz. 323.

${ }^{12}$ Wyrok SN z dnia 4 czerwca 2008 r., sygn. akt II PK 323/07, OSNP nr 21-22/2009, poz. 276.
} 
w interesie zakładu pracy zależy tylko od pracodawcy (od kierownictwa zakładu). W przeciwnym razie mogłoby dojść do dezorganizacji pracy ${ }^{13}$. Pracownik powinien podporządkować się legalnym poleceniom pracodawcy, jeśli dotyczą one pracy. Odmowa wykonania poleceń wydawanych na podstawie i w granicach art. $100 \$ 1$ k.p. nie mieści się $\mathrm{w}$ pojęciu dopuszczalnej krytyki działań pracodawcy ${ }^{14}$. Tym samym przekroczenie przez pracownika dopuszczalnych granic krytyki działań podejmowanych przez pracodawcę może stanowić uzasadnioną przyczynę rozwiązania $\mathrm{z}$ tym pracownikiem umowy o pracę za wypowiedzeniem ${ }^{15}$.

Warto także zwrócić uwagę, że obowiązek wykonywania poleceń przełożonych odróżnia stosunek pracy od wykonywania pracy w ramach zobowiązaniowych stosunków niepracowniczych np. umowy zlecenia ${ }^{16}$.

\section{Ustawowy katalog obowiązków pracowniczych}

Przepis art. 100 §2 k.p. obejmuje ustawowy katalog obowiązków pracowniczych. Nie jest to to jednak wyliczenie wyczerpujące, o czym świadczy zwrot „W szczególności”. Wymienione obowiązki dotyczą wszystkich pracowników niezależnie od rodzaju wykonywanej pracy.

\subsection{Przestrzeganie czasu pracy}

Bez wątpienia jednym $z$ ważniejszych obowiązków pracowniczych jest przestrzeganie czasu pracy ustalonego w zakładzie pracy. Pracownik zobowiązany jest przestrzegać przepisów wewnątrzzakła-

\footnotetext{
${ }^{13}$ Por. Wyrok SN z dnia 14 października 1977 r., sygn. akt I PRN 136/77, LEX nr 14431.

${ }^{14}$ Por. M. NAŁĘCZ, Obowiązki pracownika, s. 261. Z drugiej strony w wyroku z dnia 7 grudnia 2006 r., sygn. akt I PK 123/06, OSNP nr 1-2/2008, poz. 14 Sąd Najwyższy wyraził pogląd, że dozwolona i konstruktywna krytyka przez dyrektora zakładu pracy działań podejmowanych przez właściciela danej jednostki organizacyjnej nie narusza dobra pracodawcy, ale może świadczyć o dbałości pracownika o to dobro (art. 100 §2 pkt 4 k.p.).

${ }^{15}$ Por. Wyrok SN z dnia 17 grudnia 1997 r., sygn. akt I PKN 433/97, LEX nr 33982.

${ }^{16}$ Por. J. Wratny, Kodeks pracy. Komentarz, Warszawa 2013, s. 236.
} 
dowych określających czas pracy wszystkich pracowników oraz indywidualnie ustalonego dla pracownika harmonogramu czasu pracy ${ }^{17}$. Obowiązek ten obejmuje punktualne przychodzenie do pracy oraz przestrzeganie ustalonego $\mathrm{w}$ zakładzie pracy rozkładu czasu pracy. Pracownik punktualnie przychodzi do pracy a następnie pozostaje w faktycznej dyspozycji pracodawcy w określonym miejscu i czasie. W szczególnych wypadkach, zwłaszcza gdy wynika to z przepisów prawa pracy albo z decyzji pracodawcy nieobecność pracownika może być usprawiedliwiona. Natomiast samowolne opuszczenie stanowiska pracy albo samowolne zwolnienie się i nie przyjście do zakładu pracy stanowi poważne naruszenie tego obowiązku, a w konsekwencji może nawet prowadzić do rozwiązania umowy o pracę w trybie art. $52 \S 1$ pkt 1 k.p. ${ }^{18}$.

Pracodawca zatrudniający co najmniej 20 pracowników określa $\mathrm{w}$ regulaminie pracy między innymi przyjęty u danego pracodawcy sposób potwierdzania przez pracowników przybycia i obecności $\mathrm{w}$ pracy oraz usprawiedliwiania nieobecności w pracy. Natomiast w sytuacji, kiedy regulamin pracy nie zostanie wprowadzony wówczas elementy organizacji i porządku pracy, w tym sposób potwierdzania obecności w pracy, określone są w drodze poleceń pracodawcy. Dlatego odmowa wykonania tych poleceń np. odmowa podpisywania list obecności stanowi naruszenie skonkretyzowanego polecenia pracodawcy w zakresie sposobu wykonania podstawowego obowiązku przestrzegania czasu pracy oraz ustalonego w zakładzie porządku' ${ }^{19}$.

\footnotetext{
${ }^{17}$ Por. M. NAŁĘCZ, Obowiązki pracownika, s. 262.

${ }^{18}$ Por. Wyrok SN z dnia 4 grudnia 2012 r., sygn. akt I PK 142/2012, Lexis.pl nr 5179966; Wyrok SN z dnia 5 marca 2013 r., sygn. akt. II PK 174/2012, Lexis.pl nr 8362307.

${ }^{19}$ Por. Wyrok SN z dnia 7 lutego 2007 r., sygn. akt I PK 221/2006, OSNP nr 5-6/2008, poz. 67.

Zachowanie pracownika może w konsekwencji doprowadzić do rozwiązania z nim umowy o pracę. W tym kontekście warto zwrócić uwagę na stanowisko Sądu Najwyższego: „Odmowa podporządkowania się poleceniom pracodawcy dotyczącym organizacji i sposobu wykonywania umówionego rodzaju pracy stanowi
} 


\subsection{Przestrzeganie porządku i regulaminu pracy}

W każdym zakładzie pracy obowiązują określone reguły organizacyjne, które mają na celu zapewnienie niezakłóconego i prawidłowego świadczenia pracy. Przestrzeganie porządku i regulaminu pracy zapewnia pracownikom m.in. odpowiednie warunki pracy. Często pracodawcy wprowadzają pewne ograniczenia, które wydają się być skierowane przeciwko pracownikom. Jednak po głębszej analizie dochodzimy do wniosku, że te wprowadzone obwarowania np. palenie papierosów czy spożywanie posiłków jedynie w miejscach do tego specjalnie przeznaczonych zapewniają pracownikom lepszy komfort pracy, w tym zwłaszcza w zakresie czystości w miejscu wykonywania pracy.

W regulaminie pracy powinny znaleźć się postanowienia zapewniające niezakłócony tok pracy oraz ład na stanowiskach pracy. Dlatego regulamin pracy powinien przewidywać także reguły dotyczące obowiązku zachowania trzeźwości na stanowisku pracy oraz procedurę i tryb kontroli przestrzegania tego obowiązku ${ }^{20}$.

\subsection{Przestrzeganie przepisów przeciwpożarowych oraz zasad} bezpieczeństwa i higieny pracy

Podstawowym obowiązkiem każdego pracownika jest również przestrzeganie przepisów oraz zasad bezpieczeństwa i higieny pracy. Obowiązek wymieniony w art. 100 \$1 pkt 3 k.p. został uszczegółowiony w art. 211 k.p. Przestrzeganie tego obowiązku służy ochronie życia i zdrowia pracownika. Dlatego bezwarunkowo każdy pracownik powinien znać przepisy i zasady bhp, uczestniczyć w szkoleniach z tego zakresu, aby zapewnić sobie i innym współpracownikom bezpieczne warunki pracy. W niektórych zakładach pracy pracownicy zobowiązani są do używania odzieży roboczej, która zapewnia im odpowiednią ochronę. Pracownicy ci nie mogą rezygnować z tej

uzasadnioną przyczynę wypowiedzenia pracownikowi umowy o pracę" (Wyrok SN z dnia 10 maja 2000 r., sygn. akt I PKN 630/99, Lexis.pl nr 352706).

${ }^{20}$ Por. A. Kosut, Z problematyki naruszenia pracowniczego obowiązku trzeźwości, PiZS nr 3/2001, s. 33-34. 
odzieży gdyż będzie to naruszeniem omawianego obowiązku, ale także może stanowić zagrożenie dla ich zdrowia a nawet życia.

Obowiązkiem pracownika jest powstrzymywanie się od wykonywania pracy, w sytuacji gdy warunki pracy nie odpowiadają przepisom bhp i stwarzają realne zagrożenie dla zdrowia lub życia pracownika lub innych osób ${ }^{21}$. Zdaniem Sądu Najwyższego ${ }^{22}$ powstrzymanie się od wykonywania pracy zagrażającej zdrowiu pracownika (art. 210 k.p.) może w konkretnych okolicznościach sprawy stanowić przedmiot pracowniczego obowiązku dbałości o dobro pracodawcy (art. $100 \S 2$ pkt 4 k.p.). Sąd Najwyższy zwrócił bowiem uwagę, że art. 210 k.p., zezwalający pracownikowi na powstrzymanie się w określonych okolicznościach od wykonywania pracy, stanowi o pracowniczym prawie, ale uczynienie z niego użytku może się wyjątkowo aktualizować dla pracownika jako przedmiot jego równoczesnego obowiązku dbałości o dobro pracodawcy. Dlatego zamiast przebywać w nieogrzewanym pomieszczeniu i demonstrować postawę „na złość pracodawcy", a w konsekwencji występując z roszczeniami odszkodowawczymi z powodu skutków przeziębienia, pracownik powinien skorzystać z propozycji wykonywania pracy w innym pomieszczeniu (nawet we własnym mieszkaniu) albo ewentualnie zastosować bardziej efektywne urządzenie do ogrzewania, byleby nie przebywać $\mathrm{w}$ warunkach zagrażających jego zdrowiu ${ }^{23}$.

\subsection{Obowiązek dbałości pracownika o dobro zakładu pracy}

W myśl art. 100 §2 pkt 4 k.p. pracownik ma obowiązek dbać o dobro zakładu pracy, chronić jego mienie oraz zachować w tajemnicy informacje, których ujawnienie mogłoby narazić pracodawcę na szkodę. Jednak obowiązek dbałości o dobro pracodawcy to nie tylko te dwie wymienione wprost $\mathrm{w}$ przepisie powinności. Bowiem w szczególnych sytuacjach, gdy wymaga tego ważny interes pracodawcy, pracownik powinien świadczyć więcej pracy niż to wynika z jego umowy (czyli

\footnotetext{
${ }^{21}$ Por. M. NAŁĘCZ, Obowiązki pracownika, s. 263.

${ }^{22}$ Wyrok SN z dnia 7 stycznia 1998 r., sygn. akt I PKN 405/97, LEX nr 33882.

${ }^{23}$ Por. M. T. Romer, Prawo pracy. Komentarz, Warszawa 2010, s. 730.
} 
praca w godzinach nadliczbowych), a nawet powinien wykonywać pracę innego rodzaju lub też podejmować z własnej inicjatywy działania zmierzające do zapobieżenia szkodzie grożącej pracodawcy ${ }^{24}$. Ponadto z tego ogólnego obowiązku dbałości o dobro zakładu pracy można także wyprowadzić inne powinności pracownika jeżeli tylko wpłyną pozytywnie na rozwój zakładu pracy. Bez wątpienia dobra kondycja pracodawcy leży w interesie pracownika ponieważ zapewnia mu miejsce pracy i wynagrodzenie. Pracownik, który dba o dobro pracodawcy podejmuje tylko takie działania które leżą $\mathrm{w}$ interesie pracodawcy, a unika działań sprzecznych z tym interesem ${ }^{25}$.

Według Sądu Najwyższego obowiązek dbałości o dobro zakładu pracy to szczególna zasada lojalności pracownika względem pracodawcy, z której wynika przede wszystkim obowiązek powstrzymania się pracownika od działań zmierzających do wyrządzenia pracodawcy szkody, czy nawet ocenianych jako działania na niekorzyść pracodawcy. Powinność ta dotyczy każdego pracownika przy wykonywaniu uprawnień i obowiązków mających swe źródło zarówno w stosunku pracy, jak i poza tym stosunkiem. Kwestia, czy w konkretnym przypadku pracownik zachował się nielojalnie wobec pracodawcy zależy każdorazowo od okoliczności faktycznych ${ }^{26}$.

\footnotetext{
${ }^{24}$ Por. T. Liszcz, Prawo pracy, Warszawa 2009, s. 268-269. Treść obowiązku dbałości o dobro pracodawcy i ochrony jego mienia nie ogranicza się do zachowań negatywnych, ale obejmuje też powinności zachowań pozytywnych. Jednak najczęściej spotykanymi i najbardziej wymownymi przykładami naruszenia obowiązku pracowniczego o którym mowa w art. 100 §2 pkt 4 k.p. są wszelkie zachowanie pracownika skierowane bezpośrednio lub pośrednio przeciwko mieniu pracodawcy zwłaszcza jego uszkodzenie czy zniszczenie. Por. M. T. Romer, Prawo pracy, s. 732.

${ }^{25}$ Obowiązek dbałości o dobro zakładu pracy jest równoznaczny z obowiązkiem dbałości o dobro pracodawcy. Stąd też wymienione w art. $100 \S 2$ pkt 4 k.p. obowiązki mają jedynie znaczenie dopełniające do obowiązku głównego - dbałości o dobro zakładu pracy. Zob. M. SkĄPSKi, Pracowniczy obowiązek dbałości o dobro zakładu pracy (art. 104 § 2 pkt 4 k.p.), PiZS nr 2/2001, s. 9-16; T. KuCZYŃski, O właściwościach pracowniczego obowiązku dbałości o dobro zakładu pracy, PiZS nr 7/2004, s. 2-7.

${ }^{26}$ Por. Postanowienie SN z dnia 26 stycznia 2011 r., sygn. akt II PK 236/10, LEX nr 1413531.
} 
Naruszeniem obowiązku dbania o dobro zakładu pracy może być uznane podjęcie przez pracownika działalności konkurencyjnej w stosunku do działalności pracodawcy. Należy jednak postawić pytanie czy każde podjęcie przez pracownika działalności konkurencyjnej wobec pracodawcy (nawet bez zawartej umowy o zakazie konkurencji) należy traktować jako naruszenie obowiązku dbałości o dobro zakładu pracy? Odpowiedzi udzielił Sąd Najwyższy: „Nie można przyjąć, że podejmowanie działalności konkurencyjnej lub też świadczenie pracy dla konkurenta jest automatycznie równoznaczne z naruszeniem obowiązku dbałości o dobro zakładu pracy. Za takim wnioskiem przemawia w szczególności przyjmowany dotychczas sposób rozumienia obowiązku dbałości o dobro zakładu pracy oraz odmienność dóbr chronionych na podstawie art. 100 \$2 pkt 4 k.p. oraz art. 101(1) §1 k.p"27. W uzasadnieniu Sąd Najwyższy wyjaśnił, że zgodnie z przeważającym poglądem doktryny, w przypadku nie zawarcia z pracownikiem umowy o zakazie konkurencji podjęcie działalności konkurencyjnej uzasadnia $\mathrm{z}$ reguły jedynie wypowiedzenie umowy o pracę na czas nieokreślony, zaś dopuszczalność rozwiązania stosunku pracy bez wypowiedzenia na podstawie art. 52 \$1 pkt 1 k.p. (czyli ciężkie naruszenie podstawowego obowiązku pracowniczego) zachodzić będzie jedynie wyjątkowo, w przypadkach szczególnie uzasadnionych nie wywiązywaniem się pracownika ze swoich obowiązków bądź niekorzystnym wpływem dodatkowego zatrudnienia dla interesów pracodawcy. Taka kwalifikacja wymaga jednak indywidualnej oceny każdego przypadku ${ }^{28}$. Dodatkowo Sąd Najwyższy podzielając przeważający pogląd doktryny stwierdził, że obowiązek dbałości o dobro zakładu pracy należy wiązać z obowiązkiem nieszkodzenia pracodawcy. Omawianą powinność określa się z reguły,

\footnotetext{
${ }^{27}$ Wyrok SN z dnia 8 marca 2013 r., sygn. akt II PK 194/12, LEX nr 1331287.

${ }^{28} \mathrm{~W}$ doktrynie można jednak spotkać się z poglądem, że podjęcie przez pracownika działalności konkurencyjnej stanowi zawsze sytuacją niepożądaną dla pracodawcy, a zagrożenie ekonomicznych interesów pracodawcy stwarza równocześnie w każdym przypadku zagrożenie dla interesów zakładu pracy (por. M. SкĄPSKI, Pracowniczy obowiązek dbałości o dobro zakładu pracy, s. 15.
} 
jako nakaz powstrzymania się od wszystkiego, co mogłoby godzić w majątkowe i niemajątkowe interesy zakładu pracy. Ponadto każdy pracownik, podejmujący własną działalność gospodarczą, która mogłaby w jakikolwiek sposób kolidować z obowiązkami pracowniczymi wynikającymi ze stosunku pracy, powinien przejawiać szczególną dbałość, aby nie doprowadziło to do zagrożenia dobrego imienia pracodawcy. Bowiem wystarczającą podstawą wypowiedzenia umowy o pracę jest uzasadnione podejrzenie niewłaściwego wykonywania obowiązków polegających na dbaniu o dobre imię pracodawcy, w tym wykorzystywanie pozycji wynikającej z zatrudnienia u pracodawcy dla załatwienia prywatnych interesów. Dlatego pracownik, który zdecydował się na prowadzenie działalności gospodarczej konkurującej i kolidującej z jego rolą wynikającą ze stosunku pracy, powinien ją tak prowadzić, aby nie narażać pracodawcy na jakiekolwiek kłopoty ${ }^{29}$.

Pracownik dbający o dobro zakładu pracy pamięta również o przestrzeganiu tajemnicy służbowej. Ujawnienie informacji dotyczących pracodawcy może skutkować szkodą pracodawcy dlatego pracownik jest zobowiązany do przestrzegania tajemnicy służbowej (zwanej także tajemnicą zakładową). Tajemnica służbowa jest informacją uzyskaną w związku z czynnościami służbowymi albo wykonywaniem innych prac zleconych pracownikowi ${ }^{30}$.

\subsection{Obowiązek przestrzegania tajemnicy}

Obowiązek pracownika zachowania tajemnicy, oprócz tajemnicy służbowej, wynika często z uregulowań szczególnych. Ustawodawca wprowadził w ustawach szczególnych przepisy przewidujące obowiązek zachowania tajemnicy zawodowej, związanej ściśle z wykonywanym zawodem. Przykładowo w ustawie z dnia 6 lipca 1982 r. o radcach prawnych ${ }^{31} \mathrm{z}$ przepisu art. 3 wynika, że radca prawny jest obowiązany zachować w tajemnicy wszystko, o czym dowiedział się w związku

\footnotetext{
${ }^{29}$ Por. Wyrok SN z dnia 5 września 1997 r., sygn. akt I PKN 223/97, LEX nr 32681; Por. także M. T. Romer, Prawo pracy, s. 727.

${ }^{30}$ Por. T. Liszcz, prawo pracy, s. 269.

${ }^{31}$ Dz. U. z 2015 r. poz. 507, z późn. zm.
} 
z udzieleniem pomocy prawnej i jest to obowiązek nieograniczony w czasie. Z zachowania tajemnicy zawodowej radca prawny nie może być zwolniony. Z kolei w ustawie z dnia 5 grudnia 1996 r. o zawodach lekarza i lekarza dentysty ${ }^{32}, \mathrm{w}$ art. 40 ust. 1 przewidziano zasadniczo obowiązek zachowania w tajemnicy wszelkich informacji dotyczących pacjenta, o których lekarz dowiedział się z racji wykonywania zawodu (tajemnica lekarska). Natomiast w art. 11 ust. 4 ustawy z dnia 16 kwietnia 1993 r. o zwalczaniu nieuczciwej konkurencji33 ustawodawca przewidział tajemnicę przedsiębiorstwa ${ }^{34}$. Warto również wspomnieć o ustawie z dnia 5 sierpnia 2010 r. o ochronie informacji niejawnych ${ }^{35}$ w której w art. 4 ust. 1 ustawodawca wskazał, że: „Informacje niejawne mogą być udostępnione wyłącznie osobie dającej rękojmię zachowania tajemnicy i tylko w zakresie niezbędnym do wykonywania przez nią pracy lub pełnienia służby na zajmowanym stanowisku albo wykonywania czynności zleconych". Dokonano także klasyfikacji informacji i oznaczania jej określoną klauzulą „ściśle tajne”, „tajne”, „poufne” i „zastrzeżone”. W konsekwencji powstaje obowiązek właściwej ochrony tych informacji i postępowania z nimi w sposób zgodny z obowiązującymi przepisami.

Mówiąc o obowiązku przestrzegania tajemnicy bezwzględnie należy pamiętać o tajemnicy państwowej. Każdy pracownik jest zobowiązany do nieujawniania informacji mogących stanowić tajemnicę państwową niezależnie od tego czy powstanie bądź nie szkoda po stronie pracodawcy. Tajemnicą państwową objęte są wszystkie sprawy, które mogłyby zagrozić interesom państwa.

Przestrzeganie obowiązku zachowania tajemnicy m.in. zawodowej, państwowej, przedsiębiorstwa jest uzasadnione ponieważ wszystkie

\footnotetext{
${ }^{32}$ Dz. U. z 2015 r. poz. 464.

${ }^{33}$ Dz. U. z 2003 r. Nr 153, poz. 1503, z późn. zm.

34 „Przez tajemnicę przedsiębiorstwa rozumie się nieujawnione do wiadomości publicznej informacje techniczne, technologiczne, organizacyjne przedsiębiorstwa lub inne informacje posiadające wartość gospodarczą, co do których przedsiębiorca podjął niezbędne działania w celu zachowania ich poufności”.

${ }^{35}$ Dz. U. Nr 182, poz. 1228.
} 
te tajemnice w mniejszym lub większym stopniu dotyczą tajemnicy pracodawcy i są informacjami dotyczącymi zakładu pracy.

\subsection{Obowiązek przestrzegania zasad współżycia społecznego}

Zgodnie z przepisem art. 100 \$2 pkt 6 k.p. pracownik zobowiązany jest również do przestrzegania w zakładzie pracy zasad współżycia społecznego. Chodzi zatem o nakaz odpowiedniego zachowania się pracownika zwłaszcza w stosunku do współpracowników, przełożonych i podwładnych. Odpowiednie zachowanie powinno być zgodne $\mathrm{z}$ wypracowanymi w danym miejscu i czasie normami społecznymi ${ }^{36}$. Przestrzeganie zasad współżycia społecznego to obowiązek przestrzegania norm etycznych, moralnych i obyczajowych. Pracownik ma obowiązek przestrzegać zasad współżycia społecznego w zakładzie pracy. Postępowanie etyczne wpływa na dobrą i przyjazną atmosferę między współpracownikami. Jednak przestrzeganie zasad współżycia społecznego nie powinno zamykać się i kończyć w zakładzie pracy. Wzajemna pomoc, życzliwość oraz kultura osobista kształtuje prawidłowe reguły w kontaktach międzyludzkich. Obowiązek przestrzegania zasad współżycia społecznego w zakładzie pracy obejmuje również powstrzymywanie się poza miejscem i czasem pracy od takich zachowań, które wywołują lub potęgują wzajemnie negatywny stosunek współpracowników i konflikty w środowisku pracy na tle przynależności do różnych działających u pracodawcy organizacji związkowych ${ }^{37}$.

Warunkiem prawidłowego przebiegu pracy zespołowej jest harmonijne współdziałanie pracowników w zakładzie pracy. Dlatego obowiązek przestrzegania zasad współżycia społecznego odnosi się m.in. do panujących w zakładzie pracy relacji między współpracownikami. Zdecydowanie powinny to być relacje koleżeńskie oparte o zasadę wzajemnego poszanowania. Omawiany obowiązek powinien wyrażać się w poszanowaniu godności osobistej, szacunku i posłuszeństwie wobec przełożonych i podwładnych oraz wzajemnej pomocy. Dlatego

\footnotetext{
${ }^{36}$ Por. M. NAŁĘCZ, Obowiązki pracownika, s. 269.

${ }^{37}$ Por. Wyrok SN z dnia 9 lipca 2008 r., sygn. akt I PK 2/08, LEX nr 531844.
} 
używanie przemocy fizycznej czy psychicznej wobec swoich współpracowników nawet celem przymuszenia do prawidłowego wykonywania pracy jest sprzeczne z zasadami współżycia społecznego ${ }^{38}$. Zdaniem Sądu Najwyższego: „Niezależnie bowiem od wykonywania merytorycznych obowiązków pracownik pozostaje co do zasady członkiem mniejszego lub większego zespołu współpracowników i wymagane są co najmniej poprawne jego relacje $\mathrm{z}$ tym zespołem. Ustawodawca daje temu wyraz $\mathrm{w}$ art. $100 \$ 2$ pkt 6 k.p. wskazując, że do obowiązków pracownika należy także przestrzeganie zasad współżycia społecznego w zakładzie pracy. Umiejętność ich zbudowania lub utrzymania pozostaje istotna dla pracodawcy, umożliwia przecież prawidłowe funkcjonowanie. Nie można zatem odrzucać całkowicie tego elementu oceny zachowań pracownika, także przy ustalaniu, czy przywrócenie do pracy pozostaje celowe" ${ }^{39}$.

Zasady współżycia społecznego muszą być ukształtowane obiektywnie, nie mogą wynikać jedynie z woli pracodawcy. Przy czym pracodawca może stworzyć katalog zasad etycznych, obiektywnie ukształtowanych i przestrzeganych w konkretnym zakładzie pracy ${ }^{40}$. Pracodawcy informują pisemnie swoich pracowników o obowiązujących w zakładzie pracy zasadach etyki. Często w zakładach pracy obok regulaminów pracy wprowadzane są tzw. kodeksy etyki, jako kolejne przepisy wewnątrzzakładowe obowiązujące pracowników. Jednocześnie pracodawca może zastrzec, że nieprzestrzeganie wprowadzonych zasad etyki będzie traktowane jako naruszenie obowiązku pracowniczego z art. $100 \$ 2$ pkt 6 k.p. Niemniej jednak z uwagi na fakt, że zasady współżycia społecznego muszą istnieć obiektywnie a pracodawca nie może wprowadzać obowiązujących zasad według własnej subiektywnej oceny, dlatego jeżeli pracownik odmówi przestrzegania zasad etyki nie może to być oceniane jako naruszenie obowiązku pracowniczego. Zachowanie pracownika każdorazowo

\footnotetext{
${ }^{38}$ Por. Wyrok SN z dnia 5 czerwca 1987 r., sygn. akt I PRN 27/87, LEX nr 686405.

${ }^{39}$ Wyrok SN z dnia 5 lipca 2011 r., sygn. akt I PK 21/2011, Lexis.pl nr 3872605.

${ }^{40}$ Por. D. Dörre-Nowak, Prawa i obowiazki stron stosunku pracy, w: Prawo pracy i ubezpieczeń społecznych, red. K. W. Baran, Warszawa 2013, s. 347.
} 
trzeba ocenić w kontekście naruszenia obowiązku z art. 100 § pkt 6 k.p. i zastosowanych sankcji prawa pracy. Stąd sama odmowa podpisania pisma $z$ obowiązującymi w zakładzie pracy zasadami etyki nie może być jeszcze zakwalifikowana jako naruszenie obowiązku pracowniczego $^{41}$.

\section{Zakończenie}

Pracownik z chwilą nawiązania stosunku pracy, zobowiązuje się do wykonywania pracy określonego rodzaju na rzecz i pod kierownictwem pracodawcy. Sposób wykonania pracy zależy od szczegółowych obowiązków pracownika, a konkretnie od tego czy pracownik należycie spełni spoczywające na nim powinności. Podstawowe obowiązki pracownika wynikają głównie z przepisów kodeksu pracy i ustaw szczególnych, ale mogą być także przewidziane wprost w umowie o pracę.

Naruszenie podstawowych obowiązków pracowniczych wiąże się z różnymi konsekwencjami - od odpowiedzialności porządkowej, dyscyplinarnej czy materialnej ponoszonej w ramach łączącego strony stosunku pracy, po skutek w postaci rozwiązania stosunku pracy i poniesienia ewentualnej odpowiedzialności na gruncie prawa karnego. Każdorazowo rodzaj konsekwencji zależy od decyzji pracodawcy oraz charakteru obowiązku naruszonego przez pracownika.

Omówione obowiązki pracownika nie wyczerpują katalogu obowiązków wynikających $\mathrm{z}$ nawiązanego stosunku pracy. Wskazano tylko najważniejsze powinności pracownika związane ze świadczeniem pracy podporządkowanej. Konkretne obowiązki każdorazowo uzależnione są od rodzaju pracy i pełnionej przez pracownika funkcji.

\footnotetext{
${ }^{41}$ Por. Wyrok SN z dnia 5 marca 2007 r., sygn. akt I PK 228/06, OSNP nr 7-8/2008, poz. 100 .
} 


\section{The scope of the most important duties of the employee in the light of provisions of the Labour Code}

The scope of major employee's duties is governed by Art. 100 of the Labour Code. These, however, are not all employee's responsibilities towards his or her employer, but only the most common. The primary responsibility of each employee is a careful and conscientious performance of work and compliance with official instructions. Give the above, instructions must be strictly job-related and consistent with the law or the employment contract. A sample catalogue of employee's duties can be found in Art. $100 \$ 2$ of the Labour Code. It includes, for example, the duty to care for the welfare of the employment establishment and to maintain confidentiality of information, the disclosure of which could harm the employer.

An important duty of each employee is also to follow the principles of social coexistence. A violation of this duty, such as use of physical force against other employees may even lead to termination of the employment contract without notice due to the employee's fault, in accordance with Art. 52 of the Labour Code.

SŁowA KLUCzowE: pracownik, obowiązki pracownicze, prawo pracy

Key Words: employee, employee duties, Labour law

Nota o Autorze:

Dr KATARzYNA MAJCHRzAK - pracownik naukowo-dydaktyczny na Wydziale Prawa Kanonicznego Uniwersytetu Kardynała Stefana Wyszyńskiego w Warszawie, radca prawny. 